\title{
Regulatory and other barriers to urban and peri-urban agriculture: A case study of urban planners and urban farmers from the greater Chicago metropolitan area
}

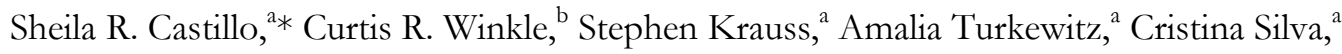 \\ and Edie S. Heinemann ${ }^{a}$ \\ University of Illinois at Chicago
}

\begin{abstract}
Submitted February 20, 2012 / Revised September 7, 2012; November 15, 2012; and February 6, 2013 /
Accepted February 7, 2013 / Published online May 8, 2013

Citation: Castillo, S. R., Winkle, C. R., Krauss, S., Turkewitz, A., Silva, C., \& Heinemann, E. S. (2013). Regulatory and other barriers to urban and peri-urban agriculture: A case study of urban planners and urban farmers from the greater Chicago metropolitan area. Journal of Agriculture, Food Systems, and Community Development, 3(3), 155-166. http://dx.doi.org/10.5304/jafscd.2013.033.001
\end{abstract}

Copyright (C) 2013 by New Leaf Associates, Inc.

\begin{abstract}
Seven perceived barriers to urban and peri-urban agriculture in the greater Chicago metropolitan area are identified through interviews with urban planners and farmers. All seven perceived barriers involve unclear or agriculture-unfriendly regulations governing urban and peri-urban agriculture. Results suggest that urban and periurban farmers commonly are being forced to operate within a legal limbo or petition for exceptions to a variety of current regulations. The study documents the need for clear and agricultureinclusive local ordinances and provides direction

\footnotetext{
${ }^{a}$ Midwest Latino Health Research, Training, and Policy

Center, University of Illinois at Chicago.

b Associate Professor, Department of Urban Planning and Policy, University of Illinois at Chicago.

* Corresponding author: Sheila R. Castillo, Associate Director, Midwest Latino Health Research, Training, and Policy Center, University of Illinois at Chicago, MC 625, 1640 West Roosevelt Road - Suite 636, Chicago, Illinois 60608 USA; +1-312-413-1104; srcastil@uic.edu
}

for local efforts to create them.

\section{Keywords}

Chicago, comprehensive plan, food planning, local food production, urban agriculture, urban planning

\section{Introduction}

Despite surging interest in urban and peri-urban agriculture, relatively little research has documented barriers to urban and peri-urban agriculture in the United States. The current study seeks to identify perceived barriers and supportive factors for urban and peri-urban agriculture by interviewing urban farmers and urban planners about their experiences with urban and peri-urban agriculture in the greater Chicago metropolitan area.

Over the past one hundred years, governance processes have evolved under conditions where urban and peri-urban agriculture was less valued than it is now. Land use regulation and urban planning sought to separate incompatible land uses, proactively eliminating the nuisances or negative externalities of agriculture from residential land in 
order to protect the health, safety, and welfare of the population (Platt, 2004). Now, however, having food production in closer proximity to residential land has become more highly valued.

Local food production is thought to support economic development (Ilbery \& Maye, 2005; Marsden, Banks, \& Bristow, 2000; Martinez et al., 2010), generate social support networks (Hinrichs, 2000; Sage, 2003), improve dietary habits (Bellows, Brown \& Smit, 2003), and have a positive environmental impact (Edwards-Jones et al., 2008). It is credited with improving health (Morgan, Marsden, \& Murdoch, 2006) and reducing urban health disparities (Conner \& Levine, 2007). Local food production can also green neighborhoods (Lovell, 2010) and may increase property values (Voicu \& Been, 2008). If properly developed, local food systems may also be able to completely meet the nutritional demands of a large American city (e.g., Kremer \& Schreuder, 2012).

In response to rising interest in local urban and peri-urban agriculture, some municipalities have begun to reform local ordinances to support agriculture. For example, Chicago made changes intended to support urban agriculture when it revised its zoning ordinance in 2011 (City of Chicago, 2012; Goldstein, Bellis, Morse, Myers, \& Ura, 2011). Other large municipalities that have started this process include Portland, Seattle, Milwaukee, Boston, Kansas City (Missouri), and San Francisco (Mukherji, 2009; Mukherji \& Morales, 2010). Smaller communities in Maine and California have also passed or considered ordinances recognizing a right to grow food (Wilce, 2011).

The planning profession, which plays a key role in the formation and dissemination of regulations that may affect urban agriculture, is just beginning to identify its relationship to the food system, and to urban agriculture in particular. Pothukuchi and Kaufman (2000) argued that planners traditionally tended to ignore the food system, in part because planners saw food as a rural agricultural issue and not as an urban issue. In an attempt to inform the planning community of the importance of the food system, the American Planning Association (APA) in 2007 issued a policy guide on urban and regional food planning. In this guide, the APA (2007) argued that planners can and should conduct community and regional food planning, and further recommended that "planners support developing land use planning policies, economic development programs, land taxation, and development regulations to enhance the viability of agriculture in the region" (p. 9). This increased interest in the food system is displayed in many efforts, such as cataloging how cities include agriculture in zoning ordinances (Goldstein et al., 2011).

Academic planning literature has begun to examine methods for planning for urban agriculture (Mendes, Balmer, Kaethler, \& Rhoads, 2008). The annual conference of the APA now regularly has sessions on food systems planning. The APA has also produced a special issue of its trade publication Planning: The Magazine of the American Planning Association that focuses on food systems planning, including urban agriculture (Bonfiglio, 2009; Flisram, 2009), and using zoning and other tools to increase the amount of healthy food in underserved neighborhoods (Shigley, 2009).

Even with scattered efforts to reform ordinances and nascent changes in the planning profession itself, it is unclear the degree to which prospective urban growers perceive local ordinances to be a barrier to urban agriculture, especially in the many thousands of local governments that have yet to consider the impacts of their regulatory structure on urban agriculture. In order to get the issue of urban food production on the agenda and focus reform efforts, systematic research is needed documenting the degree to which regulatory barriers are perceived as problematic and which regulatory barriers merit the greatest attention.

\section{Past Research on Barriers to Urban and Peri-urban Food Production}

There is evidence that many barriers still hinder urban agriculture and local food production. Lovell (2010) reviewed literature on barriers to urban agriculture and identify the following: (1) limited access to land, (2) insufficient infrastructure and supportive services, (3) intense competition from other land uses, (4) lack of research on human health risks in growing food, and (5) lack of skills and 
experience in urban agriculture. She did not identify regulatory frameworks within the myriad units of local governments as a barrier. Martinez and colleagues (2010) examined barriers to local food market expansion (as opposed to urban agriculture) and identified limitations in capacity, lack of infrastructure, lack of trace-back mechanisms to identify the source of food aggregated to supply large consumers, limited experience and training of farmers, and regulatory uncertainties. Similarly, Tropp and Barham (2008) identified needs for uniformity in food safety and processing regulations, for clarity in zoning and business permit requirements, and for better policy coordination between the national United States Department of Agriculture Food and Nutrition Services and the regional and local Women, Infants and Children offices. Lawless and colleagues (1999) identified barriers to direct markets for farmers such as community supported agriculture (CSA) operations, and indicated that farmers have an interest in working with wholesalers. Erickson and colleagues (n.d.) examined barriers to urban agriculture in Seattle, focusing primarily on local ordinances, and noted stakeholder desire for greater knowledge of who is responsible for regulation.

Only a relatively small number of studies have been conducted that ask stakeholders about what barriers they have experienced, and these studies typically are only marginally related to urban agriculture and/or urban planning. For example, Starr and colleagues (2003) looked into the perceptions and experiences of buyers and producers in Colorado to determine the major barriers to the direct marketing of local food within the region. Similarly, Peterson, Selfa, and Janke (2010) surveyed producers and institutional buyers in Kansas on their perceptions about barriers to their participation in the local food system. Most research on stakeholder experiences with barriers has focused on relatively rural regions or states, with little attention given to urban and peri-urban agriculture. As a result, it is currently unclear whether the existing research on perceptions of barriers can be extended to more urban areas, such as the greater Chicago metropolitan area.

Possibly as a result of a focus on rural areas in the literature, urban planners' perspectives on barriers to urban agriculture have never been examined. City and county planners help to determine land use, transportation networks, and the regulatory apparatus that governs agriculture and other commerce within their jurisdictions. Thus urban planners are a key stakeholder group, and their unique perceptions about urban agriculture have not been sufficiently included in the literature.

Research is needed that catalogs the producers' and planners' perceptions and experiences with barriers to urban agriculture over an entire metropolitan area that has multiple local governmental units. It is not known whether fragmented metropolitan governance and any resulting variance in regulations within a single regional food market creates barriers to urban agriculture.

\section{The Current Study}

In the current study, interviews were conducted with farmers and urban planners in the greater Chicago region on the regulatory barriers and challenges to local food production that most concern them. The greater Chicago metropolitan area, which is the subject area for the current paper, stretches from southeast Wisconsin all the way into southwest Michigan.

This paper will rely on the terms "urban" and/or "peri-urban" to refer to food grown and distributed within the greater Chicago metropolitan area. Examples of urban and peri-urban agriculture include community gardens, backyard gardens, and small to medium-scale commercial agriculture operations that typically distribute on a local level.

\section{Methods}

\section{Study Area}

The study area in this paper will be referred to as the greater Chicago metropolitan area. The greater Chicago metropolitan area consists of the Chicago Consolidated Metropolitan Statistical Area (CMSA), as defined by the U.S. Census Bureau (2010), with the addition of Berrien and Cass counties in Michigan. This was the geographic region selected by the Center of Excellence in the Elimination of Disparities (CEED@Chicago) as the area for all of its services. 
In 2010, the CMSA had a population of 9.7 million people (U.S. Census Bureau, 2010). The CMSA is anchored by the city of Chicago (population of 2.7 million), which is located in Cook County, Illinois (population of 5.2 million).

Government in the region is highly fragmented. The CMSA, as defined by the U.S. Census Bureau (2000), spans 16 counties across three states: Wisconsin, Illinois, and Indiana. Cook County alone, which includes the city of Chicago, has 131 municipalities and 244 special districts (U.S. Census Bureau, 2010).

Much of the Chicago region is relatively flat and located on fertile prairie or former swampland. Chicago is estimated to have a much larger foodshed than most areas, requiring 5.5 times as much land as an average Midwestern city to become selfsustaining ( $\mathrm{Hu}$, Wang, Arendt, \& Boeckenstedt, 2011).

\section{Participants}

Potential participants were identified with the assistance of the CEED@Chicago Food Equity Policy Committee which included members from the Chicago Metropolitan Agency for Planning and other local universities and non-profits. Potential participants were then contacted to determine whether they would be willing to be interviewed regarding their professional experience with urban agriculture and their perspective on major barriers and opportunities in urban agriculture. A total of 95 individuals were contacted and 49 agreed to participate in a one-hour interview. However, only 25 urban farmers (11 male and 14 female) and 13 urban or county planners (11 male and 2 female) were interviewed.

The urban farmers included in the study ran a very diverse set of farms. These farms ranged from community gardens operating on far less than an acre $(0.4 \mathrm{ha})$ of land to peri-urban operations using up to 500 acres (202 ha). The average farm size was 47 acres (19 ha) (SD = 131 acres (53 ha)). Of the planners interviewed, six worked for municipal governments and seven worked for county governments. Populations within their jurisdictions ranged from 11,000 to nearly 3 million. Titles ranged from directors of planning and village administrators to associate planners.

\section{The Interviews}

The interview questions were adapted from a list of questions provided by the American Planning Association that were written for urban planners regarding urban agriculture (Hodgson, Campbell, $\&$ Bailkey, 2011). Fourteen questions were adapted to ask specifically about barriers and opportunities in urban agriculture and to provide context for the interpretation of participant answer. Versions of these questions were then adapted for urban farmers.

The current paper is primarily concerned with responses to a small set of interrelated questions. Urban planners were asked, "What do you think may be regulatory challenges and/or barriers to urban agriculture in your city/county?" Urban farmers were asked, "What do you think may be regulatory challenges and/or barriers to your urban agriculture practice?" Both planners and farmers and were then asked a follow-up question, "What was done or is being done to overcome these?"

Interviews were held in person or over the phone. Interviews took around 45 minutes on average to complete. Completed interviews were transcribed so that they could be coded.

Coding was conducted by separate raters using an iterative and emergent process. In this process, an initial set of codes was created by the research team and explained to the raters, who provided feedback that the researchers used to modify the codes. Once preliminary agreement on the set of codes and its meaning was reached, raters individually coded participant answers. Two raters were assigned to each section to help ensure that the codes were applied in a consistent and accurate manner. Inter-rater agreement was then calculated using Cohen's Kappa. If substantial agreement for a code was not reached, which was indicated by a Cohen's Kappa of .60 or lower (Landis \& Koch, 1977), then that particular code was reexamined, explained again, and then was used to recode the data until substantial agreement between the raters was finally reached.

For the codes used for the urban planner interviews, the average Cohen's Kappa was .93, which indicates a nearly perfect level of agreement (Landis \& Koch, 1977). For the codes used in the urban farmer interviews, the average Cohen's 
Kappa was .81, which indicates an excellent level of agreement (Landis \& Koch, 1977).

\section{Results}

The interviews yielded a rich and diverse database of urban planners' and urban farmers' perspectives. As these results were qualitative in nature and the sample size was small, a detailed statistical analysis was not done beyond an analysis of frequency to determine the most frequently mentioned barriers. In addition, there was a strong tendency for participants to only mention the largest one or two barriers that they personally had witnessed or experienced. For example, if $28 \%$ of urban farmers mentioned barriers related to zoning codes, this means that at least $28 \%$ of urban farmers in our sample had had problems with zoning (or had seen problems) and also thought zoning was one of the largest regulatory barriers affecting them. This analysis identified the major barriers as a lack of clear and inclusive ordinances, zoning issues, limited land access, costs, access to training and certification, water issues, and insurance.

\section{Lack of Clear, Agriculture-Inclusive Ordinances}

A lack of clear ordinances that are friendly to agriculture was the most frequently mentioned barrier to urban agriculture, and was mentioned by $54 \%$ of the 13 planners and $28 \%$ of the 25 urban farmers. Planners and farmers specifically mentioned the importance of ordinances pertaining to a wide variety of agricultural activities and infrastructure, which included ordinances on farmers' markets, land use, plumbing, electricity, greenhouses, hoophouses, water access, water run-off, fencing, and shading.

There was an apparent difference between planners and farmers in their interpretation of unclear ordinances and unregulated activities. In general, farmers who mentioned unclear ordinances were bothered by these ordinances and felt uncomfortable participating in unregulated activities. Planners also saw unclear and unfriendly ordinances as a problem, but were more comfortable with unclear and silent ordinances than were farmers. As one farmer who sells directly to the public explained, "My township defined a farm stand differently in two different places in their
laws...The township supervisor keeps telling me not to worry about it but he is the fourth supervisor since I have had my business." Similarly, one planner stated that "I am an advocate [for urban agriculture]...the ordinance is silent, which gives me great latitude." Another planner stated that, as far as urban agriculture, "nothing is prohibited, [but] it's not specifically allowed, or permitted by right. It doesn't say specifically, for example, that [producing food] is a permitted use...but we don't prevent it."

Farmers reported that they felt little assurance and support for agriculture if the ordinances did not explicitly protect local food production. Without ordinances supporting a farmer's long-term security, farmers may be hesitant to make serious capital investments in land, buildings, and equipment. Overall, the farmers interviewed in this study were relatively unified in the view that additional inclusive and clear regulations are needed to support the growth of urban agriculture.

\section{Zoning That Makes Agriculture a Special Use Is Overly Specific}

Regulatory barriers related to zoning were mentioned by $31 \%$ of planners and $28 \%$ of urban farmers. Zoning codes regulate land uses and activities. Zoning codes posed an obstacle for many urban farmers, who frequently reported that that they farmed on land that was not zoned for agriculture. As one farmer put it, "Zoning is the biggest barrier, together with special-use permits."

The farmers' perspective is supported by the fact that some planners reported that the zoning code in their urban jurisdictions does not identify urban agriculture as a possible primary land use. For example, one planner indicated that in his suburb, "gardens are considered accessory use. They can be located in the side and the rear of lots." This means that special-use permits are required to use a piece of land primarily for agriculture, such as having a garden on a vacant lot. As another planner explained, "a lot could not be used solely as a community garden because an accessory use requires a primary use. So, it would need to be an exception to the zoning laws."

Applying for special-use permits can be burdensome and provides less security than a 
zoning code might. As such, many of the planners and farmers reported concerns about farming on land in urban areas. As one planner concludes, "We need to amend the current zoning codes to clarify the process of acquiring land and building a garden."

In some jurisdictions, whether agriculture is permitted fell solely on the officials' personal views. As one planner put it, "We are informal, so it really depends a lot on the personality of the zoning administrator." As such, urban farmers may find themselves at the mercy of the zoning administrator without a feasible legal recourse. Without zoning codes that recognize and protect small-scale agriculture, farmers are faced with uncertainty. As one planner explained, "I'm the zoning administrator, so if someone comes to me and asks me, 'Hey, my neighbor has a garden and is composting in the backyard. I want you to stop it.' Happily, I have not had to face that kind of question or complaint....[There is a need for] us to make it a permitted use so it's abundantly clear in the zoning ordinance." As zoning codes regulate land use, planners and practitioners reported having to follow zoning regulations that included such things as permitted plant heights and limits on the garden structures they could build, such as flower beds or greenhouses. For example, one urban farmer said that, "a zoning code would not allow for both indoor and outdoor growing" on the same piece of land. This made it necessary to get a special-use permit to build a greenhouse so that he could grow year round.

In contrast, peri-urban farmers whose land was zoned for agricultural use reported few issues. These farmers reported the ability to operate at full capacity without the interference of local officials because their agricultural activities were specifically included in zoning codes. As one peri-urban farmer put it, "zoning codes are no big deal because I live in an agricultural area. The only way it would be hard is if I lived more inside the city." Due to urban sprawl, the city also comes to peri-urban farmers, which makes peri-urban farmers in agricultural zones leery of zoning changes. As one planner explained, "there has also been a push for a mixed-use (residential and agriculture) zone.... [This] most likely will not be approved by the board because the residents who are farmers want them to stay separate."

\section{Limited Access to Land}

Having adequate access to land was mentioned as a barrier by $28 \%$ of farmers and $23 \%$ of urban planners. For those who mentioned land access as a barrier, it was frequently listed as their largest barrier. For example, multiple farmers simply stated, "The biggest challenge is access to land."

Many farmers participating in this study did not own their own land. Farmers who lease land are subject to changes made by the landowner, which may be abrupt and costly. For example, one farmer using leased land reported numerous bad experiences: "We're concerned about how much money was spent to move us from the first to the second site and then all that was lost in the move from the second site to the third site, so we are a little leery of really asking for a lot of investment in the site that might be moving in two years." In short, without long-term assurances, investments were seen as risky for farmers.

Owning or long-term leasing of land would provide assurance for the future and perhaps encourage investment. Vacant lots were commonly mentioned as a potential opportunity for urban agriculture. However, the work needed to prepare some of the vacant land was also reported to be cost-prohibitive. One grower noted the need for "a way to make land less cost-prohibitive. In other words, having more affordable ways to remediate brownfield sites that doesn't cost millions of dollars." Vacant lots, including brownfields, are tempting options for those seeing land to farm; however, they remain out of reach because of the prohibitive cost to purchase and prepare the land.

Additionally, land use and zoning regulations greatly limit the land available in more urbanized environments. Gardens in urban areas tend to be situated on residential land or parkland. Unlike agricultural land in rural areas, these zoned lots are not specifically planned for agricultural activities, making it difficult for potential users. For example, building a greenhouse may be prohibited, plant height may be restricted, water use and access may have certain regulations, and distribution may be limited. 
In contrast to more urban areas, many periurban areas have land dedicated to agriculture. However, as urban areas expand as a result of sprawl, agricultural land is eaten up by developments. As development grows, the land becomes increasingly expensive and farmers may be pushed even farther away from urban centers.

Land zoned for agriculture is commonly sold in large lots far from urban centers, which caters to the needs of large-scale corporate agriculture. One farmer expressed his disillusionment with the availability of land by saying, "[] would eventually like to buy land, but the only agricultural land available is situated on huge plots which would be too big for [my] enterprise." In addition, urban farmers frequently reported that they grew laborintensive crops, such as vegetables, particularly if they were using environmentally friendly or organic methods. Because much of the land zoned for agriculture is located far from population centers, there were some concerns about readily finding the labor needed for more labor-intensive farming, such as organic vegetable farming. This labor problem is compounded by the land commonly being sold in large lots, which would require even more labor to work.

In summary, farmers in our survey reported using all kinds of land, from traditional farms in peri-urban areas, to vacant lots, rooftops, parkland, and even brownfields. Based on information from interviews, it is clear that finding land that meets the financial, location, and land use needs of urban farmers has proven to be a major barrier for the growth of urban and peri-urban agriculture.

\section{High Costs and Lack of Funding}

Costs and funding were also reported as barriers to urban agriculture by $28 \%$ of the urban farmers. One urban farmer explained the cost of running a local community farm, "We need more funding, more technical assistance. We are also very limited in space, the garden can only grow so much and the kids can only do so much. We have a cap to the number of kids we can involve because of budget restraints. We also cannot start another garden without more people involved; it's just too big to start cleaning the lot and then finding money for the dirt and flower beds, etc."
Other urban farmers were more succinct in identifying costs and funding as a barrier created by government policy. As one farmer put it, "It's the way...the government subsidizes agriculture and it's the way we do things in this country since the 1940 s....Because of how agriculture is subsidized, you're not going to see great advances [in local agriculture], despite much effort in promoting local agriculture." The nation's food system is organized around commodity crops, which are supported through federal subsidies. However, most urban agriculture does not involve commodity crops, so no federal subsidies are gained. As another farmer put it, "The government does not support local producers; there are no subsidies for the local producers like there are for crop producers. If funding was readily available, then the operation would be much easier." The reality of subsidized crops and unsubsidized fruits and vegetables makes it more difficult for most urban farmers to find funding. This also means that there is increased financial risk for urban farmers relative to rural commodity farmers. In short, most urban farmers do not receive the same level of financial support from the government as rural commodity farmers, which places urban farmers at increased financial risk.

\section{Lack of Farmer Training and Certification}

Farmer training and certification was listed as a barrier by $23 \%$ of urban planners and $8 \%$ of farmers. Food production is difficult and requires a significant amount of training to do effectively and efficiently. Economic realities and the need for federal subsidies have driven farmers toward commercial training and specialization in growing commodity crops, which are primarily corn and soybeans in the region surrounding Chicago. As such, traditional farmer training focuses on commodity crops and does not meet farmers' needs for education in the application of sustainable, organic, urban, or varied agriculture practices. As one farmer indicated, "[food production] is really hard work. A fundamental understanding of plant growth and pesticides, soils, biology of pests, and fungal diseases is critical. Education is necessary! Agriculture is a knowledge-based science." In short, supporting a more diverse food system would 
point to the need for better farmer training options.

Similarly, several urban planners indicated their concern about small-scale farmers' access to the US Department of Agriculture (USDA) Good Agricultural Practice (GAP) certification. As one planner put it, "Local food producers need help becoming USDA GAP certified in order to be viable within the market." GAP certification is required to sell food through many distributors, as this is one of the primary ways that the federal government tries to ensure that food sold in stores is safe to eat. Another planner explained that, "not many growers are certified because there are no training facilities in Northern Illinois." Because GAP certification is only available at a limited number of training sites, which are far from the greater Chicago metropolitan area, certification may be difficult to complete. Therefore, improving opportunities for acquiring the GAP certification may address this barrier.

Some urban farmers who were interviewed appeared not to understand the importance of GAP certification, which supports the urban planners' concerns. For example, some urban farmers perceived that GAP certification, instead of being mandatory, was some sort of alternative to organic certification. As one farmer put it, "for organic farming, it's ludicrous because it's no longer about what you're doing! It's about being able to do the paperwork!...There's a system called GAP that most of the state right now is involved with and I'd rather be certified through that."

In addition to the difficulties associated with the GAP training, several urban farmers mentioned that obtaining organic certification was extremely challenging for them. As one farmer bluntly put it, "we follow organic principles... [but] we're not in a position to pursue organic certification." In short, although multiple farmers reported practicing organic methods, no one mentioned that they had obtained organic certification. The interviewers, however, did not specifically ask whether the farmers obtained organic certification, so it is very possible that only farmers who had difficulty with organic certification brought it up. Nevertheless, the extraneous paperwork and high costs of the application process were both reported as significant barriers for multiple practicing organic farmers. Frustrated by the process, one farmer gave up efforts to obtain organic certification because, "You have to be more of a bureaucrat than a farmer." This lack of certification reduces the farmer's access to markets, and makes the produce worth less once it gets to market.

In short, both the inaccessibility of GAP training and the burdensome paperwork associated with organic certification were reported as barriers to farmers becoming trained and certified. This lack of certification restricts urban farmers' options for distribution.

\section{Limited Access to Water and Dealing with $W$ ater Runoff}

Another reported challenge to urban farming was acquiring access to water and dealing with water runoff, which was reported by $20 \%$ of urban farmers and $23 \%$ of planners. For many urban farmers, a water source was important not only for watering crops, but also for preparing their crops for distribution. Access to water meant finding land already equipped with pipes and a spigot for fresh water, which was reported to be quite difficult to do by a significant portion of our sample.

If land did not have an existing water line, putting one in was reported to be prohibitively expensive. For example, as one urban farmer put it, "It is also challenging to receive water from the city....A water line move to the site, $25 \mathrm{ft}$. [7.6 m] from the street, [costs] USD25,000." Twenty-five thousand dollars is unaffordable for many urban farmers, and it even exceeds the annual operating budget reported by a few of the urban farmers in this study.

Stormwater and other water runoff was also a concern to many urban planners. As one planner explained, "There are a lot of flooding problems due to the lack of infrastructure, such as storm sewers, so deciding who is responsible may be an issue." This has led to strict stormwater ordinances, which impact urban farmers in a surprising number of ways. For example, one farmer reported that, "Stormwater ordinances prevented our plumbing permit for one of our sites.... The only way we could get around this was if the greenhouse was 
recognized as a 'Technical College' so that we could get plumbing in there."

In short, both water access and water runoff were reported as barriers for urban agriculture in the greater Chicago metropolitan area. Carefully planning for the support and growth of urban agriculture through clear and agriculture-friendly regulation of water access and water runoff may help urban agriculture continue to grow.

\section{Finding Insurance}

Insurance coverage was reported as yet another financial and logistical hurdle for urban agriculture. Insurance coverage was mentioned as a major concern by $16 \%$ of urban farmers and $8 \%$ of planners. Recognizing the need for insurance, one urban farmer complained that, "I'm having difficulty even finding companies that will give me insurance."

In addition to traditional liability insurance, environmental liability insurance also may be necessary, and both difficult and costly to obtain. As an urban farmer explains, "We were talking to a hospital about using their land, but they wanted us to have environmental liability, and that could be costly." The expense of insurance is an especially large concern for urban farmers, who tend to be operating on a small scale with narrow profit margins.

This was a surprising finding given the universal need for insurance in any enterprise. This finding may indicate that insurance companies have not yet learned how to accurately assess risk for newer forms of urban farming, such as rooftop gardens.

\section{Discussion}

Through interviews with urban planners and urban farmers, the current study identified seven barriers that hinder the growth of urban agriculture in the greater Chicago metropolitan area. The barriers are lack of clear and inclusive ordinances; zoning; land access; costs; training and certification; water; and insurance.

All seven barriers involve, at least in part, unclear or unfriendly regulations governing urban agriculture. Both urban planners and urban farmers agree that urban agriculture in the greater Chicago metropolitan area is commonly operating as an exception to current regulations or within a legal limbo, subject to the whims of local officials and the complaints of neighbors. Some planners value the flexibility afforded to them when zoning ordinances treat agriculture as a conditional use rather than as of right, but growers experience regulatory uncertainty as a barrier.

Regulatory reform could greatly reduce the time required to engage in urban agriculture. For example, Chicago has had a fairly conventional permitting process up until 2011 that was not agriculture-friendly. According to the experience of one nonprofit organization in Chicago, which was not part of the current study, it encountered delays when trying to get permits to build a greenhouse during the mid-2000s: "Once we decided to get the greenhouse funded, we started the process of the permits. It took us two years fighting with the zoning commission. They rejected our request a number of times, but finally... [after] working with the alderman's office, finally they agreed. Then, once we got the OK from the zoning department, then we had to go to the department of buildings to get the actual permits. That took over a year. [It was a] very slow process. But once we got the permits in place and everything then it only took about three months to build it." In short, the process was long and frustrating. The 2011 Chicago zoning reform made many types of agricultural operations permitted by right. This means that the zoning commission no longer needed to approve many types of urban farms and gardens, such as a greenhouse in a Chicago commercial district. Only a building permit is now required in a much streamlined process.

While ordinance reform has begun in some places, there are thousands of local governmental units in the United States and hundreds in some metropolitan areas. This study may help put reform on the agenda in some of these jurisdictions.

All the barriers identified here may be addressed to some degree by regulatory reform, but some of the barriers also imply a lack of resources: lack of government subsidies for noncommodity crops, lack of low-cost land, lack of resources for irrigation, and lack of training programs in urban agriculture. Regulatory reform, while likely to make urban agriculture more feasible, may not be 
sufficient to overcome all barriers to urban agriculture.

We see a need for additional research, innovation, and resources to help municipalities address barriers to urban agriculture. First, if local governments are to develop the will to start regulatory reform, studies are needed that examine the compatibility of land uses. For example, what is the impact of urban agriculture on land values? What is resident satisfaction with urban agriculture? Does the impact of urban agriculture depend on the type of urban agriculture being conducted?

Second, even if one is convinced that agricultural land uses are compatible with other land uses, it may be necessary to reimagine zoning and other regulations in order to find ways to allow their close proximity. Although this may be as simple as adding certain kinds of agriculture as primary or secondary uses in zoning ordinances, it also may be useful to think about ways to create districts that encourage urban agriculture. Change may be incremental, as it was for regulations that support other types of mixed-use development. For example, Euclidian zoning once kept business and residential land uses apart in Chicago's central business district by excluding housing, resulting in a central business district that, by the late 1960s, had very little activity after business hours. By the 1970s, there was a preference for multiuse blocks, which increased the use of Planned Unit Development (PUD) zoning and allowed multiple land uses to co-exist on an exceptions basis. As an exception, however, approval of PUDs was uncertain, timeconsuming, and costly. In 2011, the city of Chicago revised its central area zoning to encourage multiple uses over large areas as a right. Similar innovation and evolution may be useful in planning for urban agriculture.

Third, although the Chicago region could arguably evolve as a single foodshed, it has a very fragmented governmental structure that makes this difficult. Urban farmers could eventually benefit from regional coordination and consistency, as navigating multiple approaches to regulation quickly becomes burdensome. Model ordinances and regional leadership may help to address this, but a movement focused on the "right to grow" might stimulate the reform of ordinances in multiple jurisdictions simultaneously in order to create a predictable playing field across an entire region for urban agriculture.

A fourth area is land access. There is a need for regional studies that identify land prime for urban agriculture. Some of the factors that shape this are proximity to underserved neighborhoods, water, quality of soil, and access to food markets and labor.

Finally, additional education is needed for both planners and urban farmers. Following Soma and Wakefield (2011), our study suggests the need for additional training of planners about urban food issues. This may be done through planning schools, Certification Maintenance for American Institute for Certified Planners, and sessions at conferences. Education of prospective farmers might be accomplished by creating coalitions that focus on urban food production.

\section{Limitations}

The current study has several important limitations that should be considered. First, the study involves a fairly small number of participants, and this sample may not be representative of the overall populations of urban farmers and urban planners. In particular, because participants knew that they were to be interviewed regarding urban and periurban agriculture issues, the participants may have self-selected based on their particular interests, experiences, and concerns involving urban and peri-urban agriculture. Second, the study used open-ended questions that provided insight into the primary concerns of participants, but did not allow a quantification of some important questions, such as how many urban farmers had trouble with water access or zoning regulations. Third, the current study described the perceptions of growers and planners, but did not examine the actual ordinances. Therefore, the current study could not examine the causes and accuracy of these perceptions.

\section{Conclusions}

It is highly unlikely that the greater Chicago metropolitan area is alone in forcing many urban farmers to operate in a legal limbo or to petition for exceptions to current regulations. Until urban agriculture 
becomes a right within the law, development of urban agriculture will continue to be uncertain, time-consuming, and costly. As Chicago has recently shown, municipalities have started to show a willingness to pass ordinances that simplify their permitting processes by making agricultural activities and buildings permitted by right. This study of barriers may help in creating a friendlier regulatory environment for urban and peri-urban agriculture.

\section{References}

American Planning Association. (2007). Policy guide on community and regional food planning. Chicago: Author. Retrieved from http://www.planning.org/policy/ guides/adopted/food.htm

Bellows, A. C., Brown, K., \& Smit, J. (2003). Health benefits of urban agriculture. Retrieved from the Community Food Security Coalition website: http://www.foodsecurity.org/pubs.html\#urban ag

Bonfiglio, O. (2009). Delicious in Detroit: The city is plowing resources into its extensive stretches of vacant land. Planning: The Magazine of the American Planning Association, 75, 32-37.

City of Chicago. (2012). Urban agriculture FAQ. Retrieved August 1, 2012, from http://www.cityofchicago.org/city/en/depts/dcd/ supp_info/urban_agriculturefaq.html

Conner, D., \& Levine, R. (2007). Circles of association: The connections of community-based food systems. Journal of Hunger and Environmental Nutrition, 1, 5-25. http://dx.doi.org/10.1300/J477v01n03 02

Edwards-Jones, G., Milà i Canals, L., Hounsome, N., Truninger, M., Koerber, G., Hounsome, B., Cross, P., York, E. H., Hospido, A., Plassmann, K., Harris, I. M., Edwards, R. T., Day, G. A. S., Tomos, A. D., Cowell, S. J., \& Jones, D. L. (2008). Testing the assertion that "local food is best": The challenges of an evidence based approach. Trends in Food Science \& Technology, 19, 265-274. http://dx.doi.org/10.1016/j.tifs.2008.01.008

Erickson, L., Griggs, K., Maria, M., \& Serebrin, H. (n.d.). Urban agriculture in Seattle: Policy \& barriers. Retrieved from http:/ /www.chicagofoodpolicy.org/ Urban $\% 20$ Agriculture $\% 20$ in $\% 20$ Seattle $\% 20$ Policy $\% 20$ and $\% 20$ Barriers.pdf

Flisram, G. (2011). A serious flirt with dirt: Urban farming makes a comeback. Planning: The Magazine of the American Planning Association, 75, 14-19.

Goldstein, M., Bellis, J., Morse, S., Myers, A., \& Ura, E. (2011). Urban agriculture: $A$ sixteen city survey of urban agriculture practices across the county. Atlanta, Georgia: Turner Environmental Law Clinic. http://www.georgiaorganics.org/Advocacy/urbana greport.pdf

Hinrichs, C. C. (2000). Embeddedness and local food systems: Notes on two types of direct agricultural market. Journal of Rural Studies, 16, 295-303. http://dx.doi.org/10.1016/S0743-0167(99)00063-7

Hodgson, K., Campbell, M. C., \& Bailkey, M. (2011). Urban agriculture: Growing healthy, sustainable places, in planning advisory service. American Planning Association.

Hu, G., Wang, L., Arendt, S., \& Boeckenstedt, R. (2011). An optimization approach to assessing the selfsustainability potential of food demand in the Midwestern United States. Journal of Agriculture, Food Systems, and Community Development, 2(1), 195-207. http://dx.doi.org/10.5304/jafscd.2011.021.004

Ilbery, B., \& Maye, D. (2005). Food supply chains and sustainability: Evidence from specialist food producers in the Scottish/English borders. Land Use Policy, 22, 331-344. http://dx.doi.org/10.1016/ j.landusepol.2004.06.002

Kremer, P., \& Schreuder, Y. (2012). The feasibility of regional food systems in metropolitan areas: An investigation of Philadelphia's foodshed. Journal of Agriculture, Food Systems, and Community Development, 2(2), 171-191. http://dx.doi.org/10.5304/jafscd.2012.022.005

Landis, J. R., \& Koch, G. G. (1977). The measurement of observer agreement for categorical data.

Biometrics, 33, 159-174. http://dx.doi.org/10.2307/2529310

Lawless, G., Stevenson, G., Hendrickson, J., \& Cropp, R. (1999). The Farmer-Food Buyer Dialogue Project. Retrieved August 1, 2012, from http://www.uwcc.wisc.edu/info/ffbuyer/toc.html

Lovell, S. T. (2010). Multifunctional urban agriculture for sustainable land use planning in the United States. Sustainability, 2(9), 2499-2522. http://dx.doi.org/10.3390/su2082499

Marsden, T., Banks, J., \& Bristow, G. (2000). Food supply chain approaches: Exploring their role in rural development, Sociologia Ruralis, 40, 424-438. http://dx.doi.org/10.1111/1467-9523.00158 
Martinez, S., Hand, M., Da Pra, M., Pollock, S., Ralston, K., Smith, T., Vogel, S., \& Newman, C. (2010). Local food systems: Concepts, impacts, and issues. Washington, D.C.: USDA.

Mendes, W., Balmer, K., Kaethler, T., \& Rhoads, A. (2008). Using land inventories to plan for urban agriculture: Experiences from Portland and Vancouver. Journal of the American Planning Association, 74, 435-449.

Morgan, K., Marsden, T., \& Murdoch, J. (2006). Worlds of food: Place, power and provenance in the food chain. Oxford: Oxford University Press.

Mukherji, N. (2009). The promise and the pitfalls of municipal policy for urban agriculture (master's thesis). University of Wisconsin-Madison. Retrieved from http://cltnetwork.org/doc_library/p264UA Policy Thesis.pdf

Mukherji, N., \& Morales, A. (2010). Zoning for urban agriculture. Zoning Practice, 26, 1-8.

Peterson, H., Selfa, T., \& Janke, R. (2010). Barriers and opportunities for sustainable food systems in northeastern Kansas. Sustainability, 2, 232-251. http://dx.doi.org/10.3390/su2010232

Platt, R. (2004). Land use and society: Geography, law, and public policy. Washington, D.C.: Island Press.

Pothukuchi, K., \& Kaufman, J. (2000). The food system: A stranger to urban planning. Journal of the American Planning Association, 66(113), 24.

Sage, C. (2003). Social embeddedness and relations of regard: Alternative "good food" networks in southwest Ireland. Journal of Rural Studies, 19(1), 47-60. http://dx.doi.org/10.1016/S0743-0167(02)00044$\underline{\mathrm{X}}$
Shigley, P. (2009).When access is the issue: What cities are doing to get healthy hood into underserved neighborhoods. Planning: The Magazine of the American Planning Association, 75(8), 26-31.

Soma, T., \& Wakefield, S. (2011). The emerging role of a food system planner: Integrating food considerations into planning. Journal of Agriculture, Food Systems, and Community Development, 2(1), 1-12. http://dx.doi.org/10.5304/jafscd.2011.021.006

Starr, A., Card, A., Benepe, C., Auld, G., Lamm, D., Smith, K., \& Wilken, K. (2003). Sustaining local agriculture: Barriers and opportunities to direct marketing between farms and restaurants in Colorado. Agriculture and Human Values, 20, 301321. http://dx.doi.org/10.1023/A:1026169122326

Tropp, D., \& Barham, J. (2008). National Farmers Market Summit: Proceedings Report. USDA Agricultural Marketing Service. Retrieved August 1, 2012, from http://www.ams.usda.gov/AMSv1.0/ getfile?dDocName=STELPRDC5066926

U.S. Census Bureau. (2010). Annual estimates of the population to July 1, 2009. Retrieved from http://www.census.gov/popest/data/metro/totals 2009/tables/CBSA-EST2009-02.xls

Voicu, I., \& Been, V. (2008). The effects of community gardens on neighboring property values. Real Estate Economics, 36, 241-283. http://dx.doi.org/ 10.1111/j.1540-6229.2008.00213.x

Wilce, R. (2011, October 10). Local food ordinances from Maine to California. Center for Media and Democracy's $P R W$ atch. Retrieved from http://www.prwatch.org/news/2011/10/11034/ local-food-ordinances-maine-california 